\title{
Diversity of free-living ciliates in the sandy sediment of a Spanish stream in winter
}

\author{
B. J. Finlay, ${ }^{1 *}$ C. TÉllez ${ }^{2}$ and G. Esteban ${ }^{1,3}$ \\ ${ }^{1}$ Institute of Freshwater Ecology, Windermere Laboratory, The Ferry House, Ambleside, Cumbria LA22 OLP, UK \\ ${ }^{2}$ Departamento de Microbiología III, Facultad de Biología, Universidad Complutense, 28040 Madrid, Spain \\ ${ }^{3}$ Consejo Superior de Investigaciones Cientificas, Madrid, Spain
}

(Received 24 April 1993; revised 7 June 1993; accepted 17 June 1993)

\begin{abstract}
This study had two objectives: to determine the number of (phenotypic) ciliate species co-existing in $1 \mathrm{~m}^{2}$ of sandy river sediment at a maximum temperature of $4^{\circ} \mathrm{C}$; and to determine the ecological mechanism(s) facilitating their co-existence. The ciliate community was diverse (65 species [8 of which are new], belonging to 50 genera, from 17 orders). The sediment supported a superficial mat of diatoms ( $>30$ species). These served as food for at least 16 ciliate species. The size frequency distribution of ingested diatoms was almost identical to that for the diatoms in the sediment: thus the probability of a diatom being ingested appears to be a simple function of its relative abundance. Two factors were probably important for the co-existence of ciliate species: wide variation in cell size and shape enabled them to occupy most habitats; and they deployed a variety of feeding mechanisms to consume the variety of microbial food types. Taken as a whole, the ciliate community was capable of feeding on all microbes, including other protozoa, up to a size of about $80 \mu \mathrm{m}$. Considering the broad diversity of ciliate habitats available within $1 \mathrm{~m}^{2}$, the importance of physical transport processes in the river basin, and the known cosmopolitan distribution of many ciliate species, it is believed likely that the species richness we recorded is representative of the expanse of sandy sediment in this river, on this occasion.
\end{abstract}

\section{Introduction}

It is rarely an easy task to recognize and identify the many species of micro-organisms living in natural communities. This is especially true of most prokaryotes, because of their small size and lack of distinguishing features. These difficulties have promoted several strategies. There may be serious doubts concerning the validity of phenotypic species, and refuge may be sought in the new molecular methods of characterizing the microbial community, now largely based on sequencing rRNAs (references in Pedrós-Alió, 1993). Alternatively, the process of identifying micro-organisms on the basis of genotype or phenotype may be all but rejected, with the substitution of functional groups such as methanogens, sulphate reducers or filter feeders, in each of which the organisms have broadly similar effects upon ecosystem processes (see Chapin et al., 1992). We might also combine the benefits of different approaches, extract the more valuable characteristics of the phenotype, and

*Author for correspondence. Tel. +445394 42468; fax +445394 46914. combine these with relevant features of the genotype. This approach appears promising: within the ciliated protozoa for example, there is broad agreement between classical phylogenies based on phenotype and those based on rRNA sequences (Baroin-Tourancheau et al., 1992; Embley et al., 1992).

Here, we are concerned with free-living protozoa - the eukaryotic, unicellular, animal-like microbes which live in all aquatic and damp environments (Fenchel, 1987; Finlay, 1990). Protozoa are characteristically phagotrophic, especially on bacteria, unicellular algae and other protists, and their phagotrophy underpins their ecological importance in microbial food webs. In the open water of lakes and oceans (Berninger et al., 1991) and in anoxic sediments (Fenchel \& Finlay, 1990), they are quantitatively the most important consumers of other micro-organisms.

Our objectives were to determine the number of ciliate species co-existing in one square metre of river sediment; and to determine the ecological mechanism(s) facilitating co-existence. It would in theory have been possible to use genotypic methods alone - e.g. shotgun cloning, selection for phage clones with rRNA genes, followed by 
sequencing. But these methods are labour-intensive and they have not yet been tested in the analysis of eukaryotic community diversity (cf. analysis of prokaryote communities; e.g. Giovannoni et al., 1990). One of the benefits of genotypic methods is that they do, in principle, permit the detection and characterization of all genotypes. This highlights an inherent weakness in phenotypic methods, for these vary greatly in their efficiency. The problem is less acute in the case of the ciliates, which show a rich morphological variety, and there exist precise yet simple methods for resolving the patterns of their species-specific infraciliature. With a few exceptions, e.g. where genetic drift has occurred with the retention of some adaptive peak in phenotype (Nanney, 1982; Finlay \& Embley, 1992), it is possible to identify all species in a natural sample, using silver-staining methods. This has been done on numerous occasions, most recently by Esteban et al. (1993b): silver-staining was used to identify all 14 ciliate species in a $10 \mathrm{ml}$ sample of anoxic lake water; and seven of the species were new.

There are many published records of the numbers of ciliate species living in aquatic habitats, but it is often difficult to evaluate the data-the precision of the identifications is variable, silver staining may or may not have been used, and material may have been collected and pooled from a number of occasions and from a variety of habitats (e.g. sediment, submerged leaves, open water). It is often claimed that the combined data provide a picture of species diversity in some 'habitat' (e.g. a river or a lake) although little consideration may have been given to the dimensions of the world actually inhabited by a protozoon. A lake, a river, or a region of marine interstitial sediment will contain hundreds of protozoan habitats (see for example Fenchel, 1969; Finlay et al., 1988), such as anoxic microsites in particle aggregates, the surfaces of large planktonic diatoms, or the undersurface of a floating lily; and if a worm dies and decomposes, several generations of prostomatid ciliates may spend their entire lives within a few centimetres of the corpse. Furthermore, protozoa have short generation times and the succession of species is often rapid: species appear and 'disappear' (e.g. encyst) in a matter of weeks, and sometimes days (e.g. Fenchel, 1969; Bick, 1973; Finlay et al., 1979a). An organically-polluted river passing through the process of self-purification may appear the same from one day to the next but so far as the protozoa are concerned the habitat may be changing dramatically. The number of species recorded for a particular river during the self-purification process will tell us only how many protozoan habitats appeared, were colonized, and disappeared in the river in that period it does not necessarily tell us how many species coexist in that river.

In one sense, the aims of this study were quite modest
- we simply wanted to determine the number of ciliate species which could be identified from the phenotype, and which co-existed in a small area of homogeneous sandy sediment, in one river, at one point in time. This is probably the first time this has been attempted. Most effort was devoted to discovering every type of ciliate present and to learning all we could about their functional ecology. Finally we hoped that the information obtained would tell us something about the true diversity of ciliate species in aquatic environments generally.

\section{Methods}

Sampling site. Samples were collected from the sublittoral sandy sediment of the Río Duratón, approximately $3 \mathrm{~km}$ downstream from Sepúlveda, near Segovia in Central Spain, at an altitude of $900 \mathrm{~m}$. The sedimentary rocks are marine-reef cretaceous sandstones and limestones (Linage, 1989), and the river water is hard. Samples were collected on 3 January 1993, when the water temperature was $4{ }^{\circ} \mathrm{C}$ at midday. In many parts of the river the sediment consisted of large sandy areas (tens of square metres) beneath approximately $15 \mathrm{~cm}$ of water. The sand in the study area was apparently homogeneous, without significant quantities of leaf litter or detritus. The sediment particle size distribution was analysed later using standard sieving methods. Most of the sediment was overlain with an obvious, thin, algal mat which we subsequently discovered was composed primarily of diatoms.

Samples were collected within a $1 \mathrm{~m}^{2}$ quadrat. A $3 \mathrm{~cm}$ diameter perspex tube was pushed into the sediment to a depth of $3 \mathrm{~cm}$, capped and the tube then removed with its enclosed sediment. This was repeated 13 times at random locations within the quadrat and all sediment samples were pooled. Thus we obtained an integrated sample of the top $3 \mathrm{~cm}$ of sediment within $1 \mathrm{~m}^{2}$ of apparently homogeneous sandy sediment. It is likely that this top $3 \mathrm{~cm}$ of sediment represented most of the superficial zone in which sufficient oxygen was available to sustain an aerobic microbial community (Finlay, 1980). Approximately $50 \mathrm{~g}$ of sediment was fixed with formalin $(4 \%, \mathrm{v} / \mathrm{v}$, final concentration) and used to count and measure the diatoms (measurements were made on diatoms observed at random) and the euglenid Entosiphon. Ciliates were enumerated in live sediment using the method of Finlay $e t$ al. $(1979 b)$. Samples of the sediment were also introduced into gas-tight serum vials and cultured anaerobically as described in Esteban et al. (1993a) and subsequently sampled periodically by syringe.

Identification of ciliates. Preliminary identification of the ciliates was made on site, using a portable, low-power microscope. Thereafter, more thorough observations of living samples were made in the laboratory within $2 \mathrm{~h}$ of sampling. Samples of whole sediment were then silver impregnated (Fernández-Galiano, 1976) to reveal the infraciliature of the ciliates - the principal characteristic on which taxonomic identification was made. Semi-permanent preparations were made by preserving impregnated samples with formalin $(2 \%, v / v$, final concentration) in plastic tubes. These preparations were usable for three months. For microscopy and microphotography, the ciliates were picked out from the tubes with Pasteur pipettes and micropipettes. This process continued for a period of three months, by which time we were no longer finding new species. The principal taxonomic works used were: Kahl (1930-1935); Small \& Lynn (1985); Dragesco \& DragescoKernéis (1986); Foissner (1991); Curds (1982); Curds et al. (1983); Song \& Wilbert (1989); Esteban et al. (1993a); and references in each of these. 


\section{Results}

Species number

We recovered 65 different types of ciliates from sandy sediment within $1 \mathrm{~m}^{2}$ of stream bed. The silver-impregnated infraciliature was observed in all cases, and the differences noted (e.g. disposition and pattern of somatic and oral infraciliature, together with cell size and shape and other characteristics of cell morphology) were sufficient to claim that they were 65 separate phenotypic species. With the exception of the suctorian (of which too few individuals were recovered) all ciliates were identified to the level of genus. Forty-three of these were identified to the species level and ascribed species names from the taxonomic literature. With respect to the remaining 22 species, eight cannot be identified with reference to published works and they are all probably new species. They belong to the genera Halteria, Lacrymaria, Zosterodasys, Paranophrys, Tachysoma, Loxophyllum, Placus and Prorodon, and all appear in Fig. 1. The remaining 14 species cannot definitely be called either new or previously described species, for two reasons. Firstly, in several cases we obtained insufficient information about the infraciliature because too few cells of that species were retrieved from the sediment. Secondly, we were sometimes unable to make identifications because it was difficult to reconcile all published information, some of it incomplete, for an individual species.

Of the total number of ciliate species retrieved, all but six (Arcuospathidium vermiforme [anaerobic], Trimyema sp. and Trimyema compressum [both anaerobic], Colpidium campylum, Colpoda sp. and Tetrahymena thermophila) were obtained from the freshly-impregnated sediment samples. These six were observed only in live sediment kept in the laboratory where the stimulation of bacterial growth encouraged the development of the bacterivorous Colpidum, Colpoda and Tetrahymena, and the excystment of Colpoda. The anaerobic species found are not known to encyst. It is likely that they were

Table 1. Distribution of cell sizes of the 65 ciliates identified in sandy sediment

\begin{tabular}{cc}
\hline $\begin{array}{c}\text { Maximum } \\
\text { cell } \\
\text { dimension } \\
(\mu \mathrm{m})\end{array}$ & $\begin{array}{c}\text { Number } \\
\text { of ciliate } \\
\text { species }\end{array}$ \\
\hline$<50$ & 19 \\
$51-100$ & 29 \\
$101-150$ & 9 \\
$151-200$ & 3 \\
$201-250$ & 2 \\
$251-300$ & 2 \\
$>300$ & 1 \\
\hline
\end{tabular}

present in the trophic state in the sediment, probably in very low numbers, within anoxic microniches.

The 65 ciliate species belong to 50 genera, which are distributed between 17 orders. Systematics of ciliates at the level of higher taxa is still quite volatile. Here we have used the Small \& Lynn (1985) classification of ciliates, with the sole modification that we have allocated the Trimyema spp. to the Order Plagiopylida (we have small subunit rRNA sequence data indicating that Trimyema is very closely related to Plagiopyla; T. M. Embley \& B. J. Finlay, unpublished). The genera and Orders (the latter in parentheses) are as follows: Arcuospathidium (HAPTORIDA), Askenasia (HAPTORIDA), Aspidisca (EUPLOTIDA), Blepharisma (HETEROTRICHIDA), Caenomorpha (HETEROTRICHIDA), Calyptotricha(SCUTICOCILIATIDA), Chilodonella (CYRTOPHORIDA), Cinetochilum (SCUTICOCILIATIDA), Coleps (PRORODONTIDA), Colpidium (HYMENOSTOMATIDA), Colpoda (COLPODIDA), Ctedectoma (SCUTICOCILIATIDA), Cyclidium (SCUTICOCILIATIDA), Dexiotricha (SCUTICOCILIATIDA), Epistylis (SESSILIDA), Euplotes (EUPLOTIDA), Frontonia (PENICULIDA), Glaucoma (HYMENOSTOMATIDA), Halteria (OLIGOTRICHIDA), Homalozoon (HAPTORIDA), Lacrymaria (HAPTORIDA), Litonotus (PLEUROSTOMATIDA), Loxodes (LOXODIDA), Loxophyllum (PLEUROSTOMATIDA), Mesodinium (HAPTORIDA), Metopus (HETEROTRICHIDA), Paramecium (PENICULIDA), Paranophrys (sCUTICOCILIATIDA), Philasterides (SCUTICOCILIATIDA), Placus (PRORODONTIDA), Pleuronema (SCUTICOCILIATIDA), Prorodon (PRORODONTIDA), Pseudomicrothorax (CYRTOPHORIDA), Sagittaria (PRORODONTIDA), Saprodinium (ODONTOSTOMATIDA), Sathrophilus (SCUTICOCILIATIDA), Spirostomum (HETEROTRICHIDA), Stentor (HETEROTRICHIDA), Strombidium (OLIGOTRICHIDA), Stylonychia (STICHOTRICHIDA), (Suctorian) (sub-class sUCTORIA), Tachysoma (STICHOTRICHIDA), Tetrahymena (HYMENOSTOMATIDA), Thigmogaster (CYRTOPHORIDA), Trimyema (PLAGIOPYLIDA), Trithigmostoma (CYRTOPHORIDA), Urosoma (STICHOTRICHIDA), Urotricha (PRORODONTIDA), Vorticella (SESSILIDA), Zosterodasys (CYRTOPHORIDA).

The ciliates recovered spanned a particularly broad size range: from $15 \mu \mathrm{m}$ (Cinetochilum margaritaceum) to about $500 \mu \mathrm{m}$ (Spirostomum minus), although most were less than $100 \mu \mathrm{m}$ in length (Table 1, Fig. 1).

\section{Sediment characteristics}

The sediment was composed mainly of fairly coarse sand particles (median grain diameter $300 \mu \mathrm{m}$ ) with a silt and clay fraction $(<62 \mu \mathrm{m})$ accounting for $2 \%$ of total weight. The sediment was covered with a diatom mat which was obvious to the unaided eye. The mat probably secreted mucilage: this would explain the production of microscopic particle aggregates observed in the superficial sediment layer. 


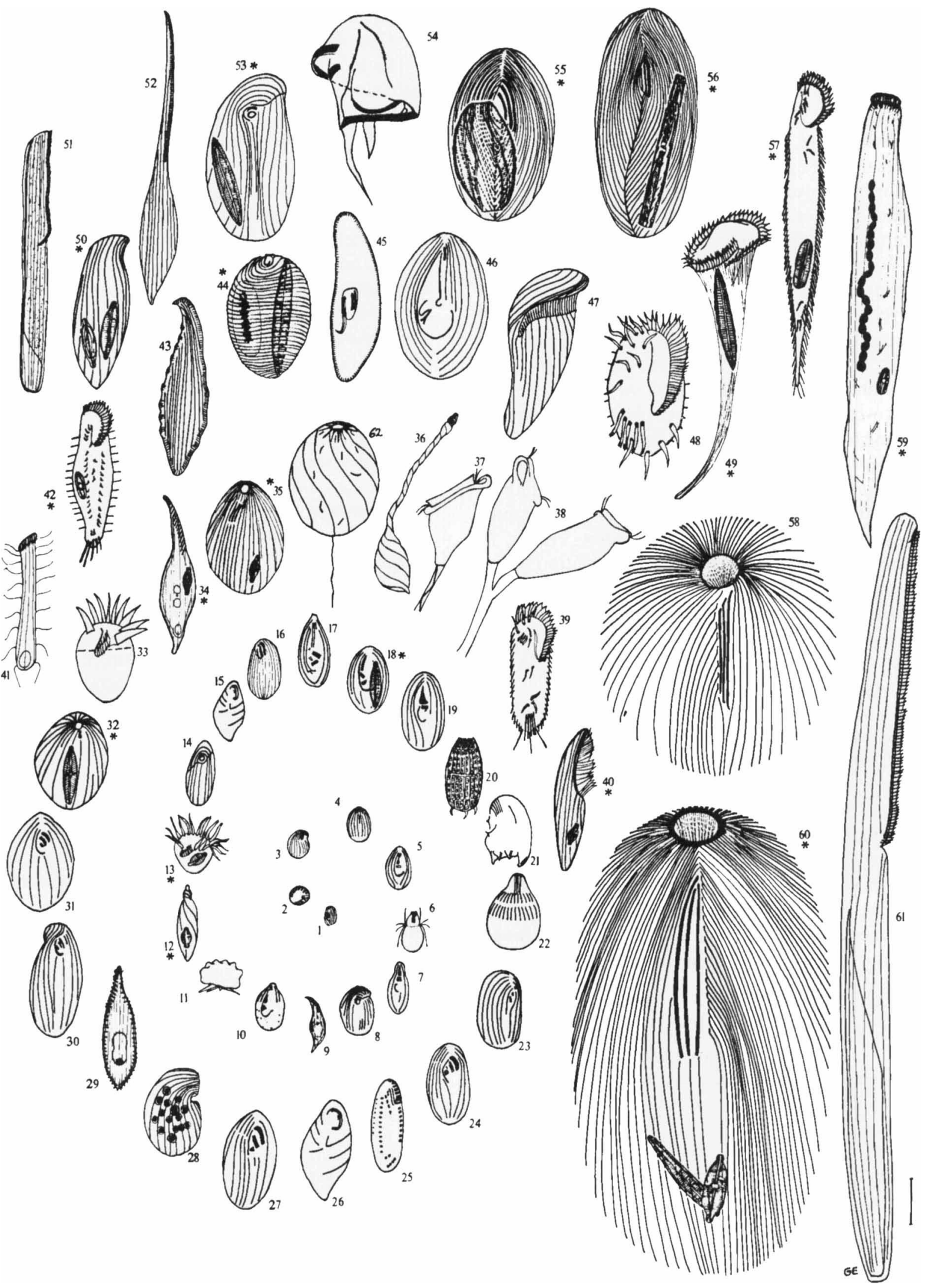




\section{Diatom ingestion}

The diatoms in the mat were very abundant $(1.47 \times$ $10^{6} \mathrm{~cm}^{-2}$ ) and easily discriminated from each other on the basis of size $(4-220 \mu \mathrm{m})$, shape and frustule architecture. They are probably all separate species (total number $>30$ ). The diatoms $<40 \mu \mathrm{m}$ in length were numerically dominant. When all diatoms in the community are plotted as a size frequency distribution (Fig. 2), it becomes clear that some sizes are particularly abundant (distinct peaks at 12, 19, 26, 38 and $49 \mu \mathrm{m}$ ). There is, moreover, remarkably good agreement between this frequency distribution and that for the diatoms ingested by the protozoa. Sixteen ciliate genera were observed with diatom ingesta (see Fig. 1 asterisks). There was considerable overlap in the sizes of diatoms ingested by different ciliates, but the maximum size ingested was positively correlated with overall ciliate length. Big ciliates, such as Frontonia acuminata $(110 \mu \mathrm{m})$ ate big diatoms but they also ingested small diatoms (total size range ingested 9-107 $\mu \mathrm{m})$. Prorodon palustris $(300 \mu \mathrm{m})$ fed on a narrower size range $(20-70 \mu \mathrm{m})$. Small scuticociliates $(<50 \mu \mathrm{m})$ ingested only small diatoms, in the size range 4-21 $\mu \mathrm{m}$. The largest diatoms $(>200 \mu \mathrm{m})$ were not eaten by any protozoa and ingestion of diatoms larger than $80 \mu \mathrm{m}$ was rare.

\section{Discussion}

It is remarkable that we have recovered representatives of 17 orders of ciliates from $1 \mathrm{~m}^{2}$ of sandy sediment in one river in Spain. It is even more remarkable because the total number of orders of free-living ciliates (i.e. described from marine, freshwater and terrestrial environments) is only 36 . How does the richness of this ciliate community compare with that described in other published work? As mentioned earlier, there are few if any other studies which are directly comparable. Grabacka (1971), Webb (1961), Wang (1928) and Small (1973) recorded 62, 93, 109 and 155 species respectively; but, with the exception of the last of these, silver-staining methods were not used. In all four cases, the species total refers to a variety of habitats, sampled on several to many occasions. The length of these species lists is probably a function of the variable intensity and duration of the investigation.

Where the study was more limited with respect to the size of the habitat investigated, and confined to one occasion, numerous studies in freshwater have yielded species numbers in the range 7-36 (e.g. Curds et al., 1986; Finlay et al., 1987; Esteban et al., 1993b). In marine sediments, at least 21 species were found living $12-15 \mathrm{~cm}$ deep in sandy sediment, and 26 species were recorded from the Nivå sulphuretum (Fenchel, 1969).

It is a little easier to compare our data with those obtained by Foissner et al. (1992), who also had an interest in finding all ciliate taxa present, at six stations on the River Amper near Munich, Germany. They used silver staining, and they present data for species richness on single occasions. The sample obtained for each 'station-occasion' was an integrated sample of a variety of protozoan habitats. Each of the six stations was investigated two or three times and each time, three 'direct' samples were taken to include all habitats available (mud, vegetation, twigs, leaf litter, gravel, etc.), and an integrated count of species number obtained. The number of species recorded at each station-occasion was in the range 38-77 (arithmetic mean 54). It is interesting that of the 209 ciliate taxa they list from the whole study, only $18(9 \%)$ were unidentified to the level of species,

Fig. 1. Ciliate species (and the euglenid Entosiphon sp.) identified in Duratón River sediment. 1, Cinetochilum margaritaceum (Ehrenberg, 1831); 2, Halteria n. sp.; 3, Thigmogaster sp.; 4, Urotricha sp.; 5, Cyclidium citrullus Cohn, 1865; 6, Mesodinium sp.; 7, Philasterides sp.; 8, Chilodonella uncinata (Ehrenberg, 1838); 9, Litonotus uninucleatus (Kahl, 1931); 10, Cyclidium plouneouri Dragesco, 1963; 11, Aspidisca cicada (Müller, 1786); 12, Lacrymaria n. sp.; 13, Halteria grandinella (Müller, 1773); 14, Zosterodasys n. sp.; 15, Trimyema sp.; 16, Glaucoma scintillans Ehrenberg, 1830; 17, Ctedectoma wilberti (Small \& Lynn, 1985); 18, Calyptotricha lanuginosa (Penard, 1922); 19, Paranophrys n. sp.; 20, Coleps hirtus (Müller, 1786); 21, Saprodinium sp.; 22, Askenasia sp.; 23, Pseudomicrothorax dubius (Maupas, 1833); 24, Sathrophilus muscorum Kahl, 1931; 25, Tachysoma n. sp.; 26, Trimyema compressum Lackey, $1925 ; 27$, Dexiotricha media Peck, 1974; 28, Colpoda cucullus (Müller, 1773); 29, Loxophyllum n. sp.; 30, Colpidium campylum (Stokes, 1886); 31, Tetrahymena pyriformis-complex; 32, Placus n. sp.; 33, Strombidium sulcatum Claparède \& Lachmann, 1859; 34, Litonotus fasciola (Müller, 1773); 35, Prorodon n. sp.; 36, Lacrymaria olor (Müller, 1786); 37, Vorticella sp.; 38, Epistylis sp.; 39, Stylonychia putrina Stokes, 1885; 40, Blepharisma hyalinum Perty, 1849; 41, Arcuospathidium vermiforme Foissner, 1984; 42, Tachysoma pellionella (Müller, 1773); 43, Loxophyllum helus (Stokes, 1884); 44, Entosiphon n. sp.; 45, Paramecium aurelia - complex; 46, Pleuronema coronatum Kent, 1881; 47, Metopus es Müller, 1786; 48, Euplotes patella (Müller, 1773); 49, Stentor sp.; 50, Loxodes striatus (Engelmann, 1862); 51, Spirostomum teres (Claparède \& Lachmann, 1858-1859); 52, Litonotus cygnus (Müller, 1773); 53, Trithigmostoma cucullulus (Müller, 1786); 54, Caenomorpha sp.; 55, Frontonia acuminata (Ehrenberg, 1833); 56, Frontonia leucas Ehrenberg, 1838; 57, Urosoma cienkowski Kowalewski, 1882; 58, Prorodon discolor Ehr.-Blochm.-Schew.; 59, Homalozoon vermiculare (Stokes, 1887); 60, Prorodon palustris De Puytorac \& Savoie, 1968; 61, Spirostomum minus (Roux, 1901); 62, Sagittaria poligonalis Grandori, 1934. In addition, four ciliate species (unidentified or observed only in cultivated sediment) do not appear in this figure: (63), unidentified suctorian; (64), Scuticociliate, Loxocephalus like; (65), Cyclidium porcatum Esteban, 1993 (from culture); (66), unidentified stichotrich (anaerobic; from culture). Scale bar, $30 \mu \mathrm{m}$. Asterisks denote species with ingested diatoms at the time of sampling. 


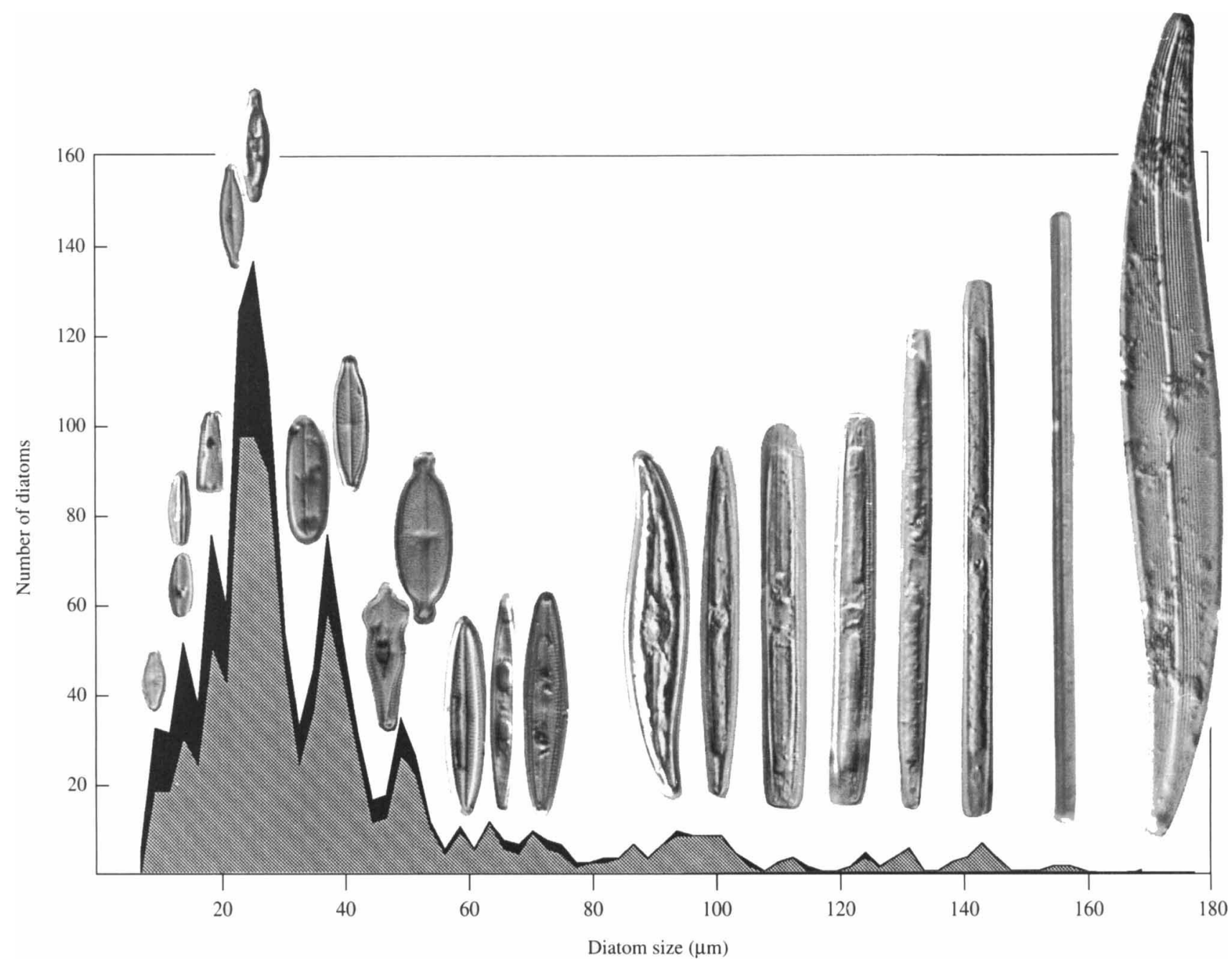

Fig. 2. Size frequency distribution of free-living diatoms ( $n=997$; hatched area), and diatoms ingested ( $n=240$; area shaded black) by ciliates and Entosiphon sp. Photographs of the most abundant diatom species are superimposed where appropriate. The largest diatom shown is $220 \mu \mathrm{m}$ long.

and some of these could have been new species. Note that 12 years previously, in a similarly intense study of small water bodies in the Austrian Alps, Foissner (1980) discovered 194 ciliate species, $34 \%$ of which were new to science. Taken together with the results of our study we might infer (a) that, with the exception of some rare or unusual habitats (e.g. Esteban et al., 1993 b), the number of free-living freshwater phenotypic ciliate species waiting to be discovered is decreasing rapidly, and $(b)$ undiscovered species represent approximately $20 \%$ of the current total.

\section{Co-existence}

How do 65 ciliate species co-exist in a small area of sandy sediment in a river? Our knowledge of the community is restricted to information obtained at one moment in time, so our conclusions are, necessarily, tentative. Furthermore, some of the species are here described for the first time, so our knowledge of their functional biology is incomplete.

Some relevant information is readily acquired: the sizes and shapes of the ciliates, their modes of feeding (e.g. filter-feeding, raptorial), the types and sizes of food particle they ingest and their modes of locomotion. The extremely broad range of ciliate sizes $(15-500 \mu \mathrm{m})$ has already been described (Table 1). The first important consequence of this is that there will be very few spaces too small to admit grazing ciliates, and they may even invade organic particle aggregates. Secondly, as the sediment is composed mainly of fairly coarse sand particles, a true interstitial habitat is created, as it is in marine sandy sediments; so long ribbon-like ciliates, e.g. 
Spirostomum and Homalozoon, are free to penetrate. The smaller particle aggregates are the principal domain of the smaller browsing ciliates such as Aspidisca and the small cyrtophorids; while the larger aggregates provide a surface for the larger 'walking' browsers (especially Euplotes and the stichotrichs).

The ciliate community also displays a surprising diversity of feeding types. Pre-eminent among the filter feeders are the scuticociliates, most falling within the size range $15-50 \mu \mathrm{m}$ and specialized for the ingestion of different size ranges from the spectrum of sizes of suspended bacteria (see Fenchel, 1986). The exceptional scuticociliate is Calyptotricha lanuginosa; it is capable of ingesting diatoms and it secures its own 'spatial niche' by living in a lorica. There was evidence that at least one small non-filter-feeding ciliate (Mesodinium) was feeding on bacteria. Halteria grandinella and Halteria $\mathrm{n}$. sp. were the only small ' upstream' filter feeders (i.e. filtering with an adoral zone of membranelles). Small diatoms were the only identifiable ingesta in $H$. grandinella but it is likely that it was also feeding on small green algae as it does in other habitats (Finlay et al., 1988). Diatom-feeding was distributed amongst the larger ciliates, irrespective of their 'normal' mode of feeding. Thus, the raptors Loxodes striatus and Trithigmostoma cucullulus, the peniculines (with secondarily-adapted raptorial feeding) Frontonia acuminata and $F$. leucas, the raptorial haptorid Homalozoon vermiculare, the heterotrich Stentor sp., the prorodontids Prorodon spp. and Placus n. sp., and the stichotrichs Tachysoma pellionella and Urosoma cienkow$s k i$ all showed signs of diatom ingesta.

The clearest evidence for food niche separation is also provided by the diatoms. There was remarkably good agreement between their size frequency distribution and that for the diatoms ingested by the protozoa. This suggests that the probability of a diatom being ingested is dependent on mechanical factors (rather than 'taste' for example): diatoms which are very abundant are encountered more frequently and thus ingested more frequently. Size of ciliates is the only important constraint. Small ciliates do eat diatoms, but no ciliate is capable of breaking or digesting the diatom frustule, so the maximum size of diatom that can be ingested is close to the maximum length to which the ciliate can be stretched. This correlation between the size of the ciliate predator and the typical size of its prey has been well documented (e.g. Fenchel, 1968, 1986; Finlay \& Berninger, 1983). It is possible, however, that in the case of a few large ciliate species in the Duratón, particularly those which are principally filter feeders (Tachysoma, Urosoma, Stentor, Blepharisma) on relatively small particles $(<5 \mu \mathrm{m})$, this relationship does not hold true. Too few specimens of Homalozoon vermiculare or Prorodon palustris were observed to say if the pre- ponderance of small ingested diatoms they contained are typical.

On this one occasion, 16 ciliate species were recovered with diatom ingesta but, with the probable exception of the cyrtophorids, it is likely that the diatoms did not account for the total diet in any of these ciliates. All are known to ingest other particulate food, especially small algae and flagellates, and in many cases, a proportion of the ingesta was unrecognizable. It is likely that many of these ciliates supplement their diet with other food and that this flexibility broadens the capacity for co-existence in the community. Finally, the ciliate community contained the predatory ciliates Litonotus and Loxophyllum. These have toxicysts, which are used for killing motile prey, especially small protists.

There is little doubt that the diversity and abundance of diatoms in this sandy sediment contribute greatly to the diversity and abundance of ciliates observed. This in itself is not a new discovery (e.g. Picken, 1937; Gray, 1952; Fenchel, 1968, 1969). Fenchel (1969), for example, identified a total of 84 species or genera of ciliates in marine sandy sediment, of which 15 fed exclusively on diatoms. In the case of another 31 forms, diatoms were an important part of the diet. It is also well known that different ciliate species can co-exist by feeding on different size classes of diatoms (Finlay \& Berninger, 1983; Fenchel, 1969, 1987).

Thus, several factors contribute to the co-existence of so many ciliate species: their great variation in size and shape enables them to occupy a variety of habitats, they are represented by a diversity of feeding types; and the combination of the range in ciliate size with variety of oral structures and feeding types permits consumption of most other microbes in the community up to a size of about $80 \mu \mathrm{m}$. The diversity of the ciliate community is completed by the presence of several species which prey on protists in the community.

\section{Patch size and the true species number}

What can we infer from the number of species found in $1 \mathrm{~m}^{2}$, and how does this relate to larger areas of river sediment? It is true that by integrating our small samples we may have selected from several population patches. But it may also be true that each individual sample removed an area that was larger than the patch size of an individual species-population. We simply do not know, and there is very little information available in the literature concerning the patch sizes of natural protozoan populations. Fenchel's (1990) study is the most relevant. The bacteria-feeding ciliates Pseudocohnilembus and Uronema have polymorphic life cycles with dispersal stages which seek out patches of elevated bacterial concentration. When starved, Pseudocohnilembus forms 
motile swarmers, about half of which subsequently form cysts, and the spatial distribution of these cysts in a $1.5 \mathrm{~m}^{2}$ area of marine sediment indicated that the patch size was approximately the same as the total area sampled. Furthermore, in the case of the dispersal stage of Uronema, the mean lateral displacement during its lifetime was approximately $40 \mathrm{~cm}$, so a circle with a radius of $40 \mathrm{~cm}$ might be considered the spatial range of a Uronema cell. This information, if broadly applicable to the Duratón ciliates, is consistent with the idea that sampling within $1 \mathrm{~m}^{2}$ may have encompassed all, or the greater part of, individual population patches in the case of many of the ciliate species. It is also possible that the patch sizes may be even larger than this: diatoms, their mucilage, and sediment particles existed as a loosely bound superficial layer, and the habitat thus created provided ciliates with shelter from the effects of turbulence and the flow of river water. But occasional disturbance and displacement of sediment is inevitable, so the patch size, if indeed this is a realistic concept for river-dwelling ciliates, must be larger than it would be in a turbulence-free system.

\section{Species number - extrapolation}

If we had sampled a much larger area of this sandy sediment, how many more species would we have found? The additional number would probably not have been very great, for the following reasons. (a) Most, if not all, of the ciliates and their habitats found within $1 \mathrm{~m}^{2}$ of sandy sediment will exist elsewhere. Physical transport processes (e.g. turbulence and the flow of water) will ensure that this is so. (b) In addition, ciliates tend to have very large population sizes (total ciliate abundance in the Duratón sediment was $\left.1620 \mathrm{~cm}^{-2}\right)$; so the probability of local extinctions, and of speciation leading to endemism, is, in both cases, low (T. Fenchel, personal communication). (c) In short, the same ciliate species are likely to be found in the same habitat types in different parts of the river. If this reasoning is applied on a global scale, then the total number of ciliate species living in river sediments may be quite modest.

There is some support for these ideas in the data we present here. Only eight of the 65 species are new. At least 43 of the remainder have been described from locations in geographically distant areas e.g. Kahl (1930-35) in Northern Germany, Foissner et al. (1991) in Austria and Central Europe, and Dragesco \& DragescoKernéis (1986) in Central Africa. If a large proportion of the ciliates living in a small area of sandy stream bed in Spain also have a cosmopolitan distribution, there is little reason to believe that the number of ciliate species in a large area of sandy stream bed is significantly larger than the number we recorded.
This work received financial support from the Natural Environment Research Council (UK), the British Council (MDR/980/2 (93/94) 1337), Dirección General de Investigación Científica y Técnica no. PB 91-0384, and Consejo Superior de Investigaciones Científicas (G.E.).

\section{References}

Baroin-Tourancheau, A., Delgado, P., Perasso, R. \& Adoutte, A. (1992). A broad molecular phylogeny of ciliates: identification of major evolutionary trends and radiations within the phylum. Proceedings of the National Academy of Sciences of the United States of America 89, 9764-9768.

Berninger, U.-G., Caron, D. A., Sanders, R. W. \& Finlay, B. J. (1991). Heterotrophic flagellates of planktonic communities, their characteristics and methods of study. In The Biology of Free-Living Heterotrophic Flagellates, pp. 39-56. Edited by D. J. Patterson \& J. Larsen. Oxford: Clarendon Press.

BiCK, H. (1973). Population dynamics of protozoa associated with the decay of organic materials in fresh water. American Zoologist 13, 149-160.

Chapin, F. S., Schulze, E.-D. \& Mooney, H. A. (1992). Biodiversity and ecosystem processes. Trends in Ecology and Evolution 7, 107-108.

CuRds, C. R. (1982). British and Other Freshwater Ciliated Protozoa. Part 1. Ciliophora: Kinetofragminophora. London: Cambridge University Press.

Curds, C. R., Gates, M. A. \& RoberTs, D. McL. (1983). British and Other Freshwater Ciliated Protozoa. Part 2. Ciliophora: Oligohymenophora and Polyhymenophora. Cambridge : Cambridge University Press.

Curds, C. R., Bamforth, S. S. \& Finlay, B. J. (1986). Report on the freshwater workshop in Kisumu, Kenya (30 June-5 July 1985). Insect Science and its Applications 7, 447-449.

Dragesco, J. \& Dragesco-Kernéis, A. (1986). Ciliés Libres de I Afrique Intertropicale. Paris: ORSTOM.

Embley, T. M., Finlay, B. J., Thomas, R. H. \& Dyal, P. L. (1992). The use of rRNA sequences and fluorescent probes to investigate the phylogenetic positions of the anaerobic ciliate Metopus palaeformis and its archaeobacterial endosymbiont. Journal of General Microbiology 138, 1479-1487.

Esteban, G., Guhl, B. E., Clarke, K. J., Embley, T. M. \& Finlay, B. J. (1993a). Cyclidium porcatum n. sp.: a free-living anaerobic scuticociliate containing a stable complex of hydrogenosomes, eubacteria and archaeobacteria. European Journal of Protistology 29, 262-270.

Esteban, G., Finlay, B. J. \& Embley, T. M. (1993b). New species double the diversity of anaerobic ciliates in a Spanish lake. FEMS Microbiology Letters 109, 93-100.

FENCHEL, T. (1968). The ecology of marine microbenthos. II. The food of marine benthic ciliates. Ophelia 5, 73-121.

FENCHEL, T. (1969). The ecology of marine microbenthos. IV. Structure and function of the benthic ecosystem, its chemical and physical factors and the microfauna communities with special reference to the ciliated protozoa. Ophelia 6, 1-182.

Fenchel, T. (1986). Protozoan filter feeding. Progress in Protistology 1, $65-113$.

FENCHEL, T. (1987). Ecology of Protozoa. Madison: Science Tech Publishers/Berlin: Springer-Verlag.

FENCHEL, T. (1990). Adaptive significance of polymorphic life cycles in protozoa: responses to starvation and refeeding in two species of marine ciliates. Journal of Experimental Marine Biology and Ecology 136, 159-177.

FENCHEL, T. \& FinLAY, B. J. (1990). Anaerobic free-living protozoa: growth efficiencies and the structure of anaerobic communities. FEMS Microbiology Ecology 74, 269-276.

FernáNDEZ-Galiano, D. (1976). Silver impregnation of ciliated protozoa: procedure yielding good results with the pyridinated silver carbonate method. Transactions of the American Microscopical Society 95, 557-560.

FINLAY, B. J. (1980). Temporal and vertical distribution of ciliophoran communities in the benthos of a small eutrophic loch with particular reference to the redox profile. Freshwater Biology 10, 15-34. 
Finlay, B. J. (1990). Physiological ecology of free-living protozoa. Advances in Microbial Ecology 11, 1-35.

FINLAY, B. J. \& BERNINGER, U.-G. (1983). Coexistence of congeneric ciliates (Karyorelictida: Loxodes) in relation to food resources in two freshwater lakes. Journal of Animal Ecology 53, 929-943.

Finlay, B. J. \& EmbleY, T. M. (1992). On protozoan consortia and the meaning of biodiversity. Society for General Microbiology Quarterly 19(3), 67-69.

Finlay, B. J., Bannister, P. \& Stewart, J. (1979a). Temporal variation in benthic ciliates and the application of association analysis. Freshwater Biology 9, 45-53.

Finlay, B. J., LAYBoURN, J. \& StrachaN, I. (1979 $b$ ). A technique for the enumeration of benthic ciliated protozoa. Oecologia 39, 375-377.

Finlay, B. J., CURDS, C. R., BAMForTH, S. S. \& BAForT, J. M. (1987). Ciliated protozoa and other microorganisms from two African soda lakes (Lake Nakuru and Lake Simbi, Kenya). Archiv für Protistenkunde 133, 81-91.

Finlay, B. J., Berninger, U.-G., Clarke, K. J., Cowling, A. J., Hindle, R. M. \& Rogerson, A. R. (1988). On the abundance and distribution of protozoa and their food in a productive freshwater pond. European Journal of Protistology 23, 205-217.

FOISSNER, W. (1980). Artenbestand und Struktur der Ciliatenzönose in alpinen Kleingewässern (Hohe Tauern, Österreich). Archiv für Protistenkunde 123, 99-126.

Foissner, W., Blatterer, H., Berger, H. \& KohmanN, F. (1991). Taxonomische und ökologische Revision der Ciliaten des Saprobiensystems. I: Cyrtophorida, Oligotrichida, Hypotrichia, Colpodea. Munich: Bayer. Landesamtes für Wasserwirtschaft.

FoIsSNER, W., UNTER WEger, A. \& HeNSCHEL, T. (1992). Comparison of direct stream bed and artificial substrate sampling of ciliates (Protozoan, Ciliophora) in a mesosaprobic river. Limnologica 22, 97-104.
GraBACKA, E. (1971). Ciliata in bottom sediments of fingerling ponds. Polish Archives of Hydrobiology 18, 225-233.

Giovannoni, S. J., Britschai, T. B., MoYer, C. L. \& Field, K. G. (1990). Genetic diversity in Sargasso Sea bacterioplankton. Nature, London 345, 60-62.

GraY, E. (1952). The ecology of the ciliate fauna of Hobson's Brook, a Cambridgeshire chalk stream. Journal of General Microbiology 6, 108-122.

KAHL, A. (1930-1935). Urtiere oder Protozoa. I. In Die Tierwelt Deutschlands, pp. 1-886. Edited by F. Dahl. Jena: G. Fischer.

LinaGe, A. (1989). Sepúlveda y el Cañón del Duratón, pp. 159. León (Spain): Ediciones Lancia.

NanNEY, D. L. (1982). Genes and phenes in Tetrahymena. Bioscience 32, 783-788.

Pedrós-Alió, C. (1993). Diversity of bacterioplankton. Trends in Ecology and Evolution 8, 86-90.

Picken, L. R. (1937). The structure of some protozoan communities. Journal of Ecology 25, 368-384.

Small, E. B. (1973). A study of ciliate protozoa from a small polluted stream in east-central Illinois. American Zoologist 13, 225-230.

Small, E. B. \& LYNN, D. H. (1985). Phylum Ciliophora Doflein, 1901. In An Illustrated Guide to the Protozoa, pp. 393-575. Edited by J. J. Lee, S. H. Hutner \& E. C. Bovee. Lawrence, Kansas: Society of Protozoologists.

SONG, W. \& WILBERT, N. (1989). Taxonomische Untersuchungen an Aufwuchsciliaten (Protozoa, Ciliophora) im Poppelsdorfer Weiher, Bonn. Lauterbornia 3, 2-221.

WANG, C. C. (1928). Ecological studies of the seasonal distribution of protozoa in a fresh-water pond. Journal of Morphology 46, 431-478.

WeBB, M. G. (1961). The effects of thermal stratification on the distribution of benthic protozoa in Esthwaite Water. Journal of Animal Ecology 30, 137-151. 